Industrial Health, 1985, 23, 289-293.

\title{
Influence of Age on Cardiorespiratory Responses of Firefighters During Exercise in the Heat
}

\author{
Key words: Age differences-Exercise in the heat-Firefighter-Sweat rate- \\ Cardiorespiratory responses
}

Severe work load in heat represents an occupational hazard for firefighters because it brings about intense cardiorespiratory responses. ${ }^{1,2)}$ Since the average age of firefighters in Japan is expected to increase in the future, ${ }^{3)}$ it is becoming an urgent problem to assess the influence of aging on the cardiorespiratory responses of firefighters when they work in heat. This study was undertaken to investigate the age differences in cardiorespiratory responses during exercise in the heat when firefighters wore protective clothing and equipment.

Forty professional firefighters of the Tokyo Fire Defense Board, all in good health, volunteered to participate in the experiments. The subjects were all men and divided into four age groups, 10 being aged 20-28 years (group 1), 11 aged 30-38 years (group 2), 12 aged 40-46 years (group 3) and seven aged 50-56 years (group 4). The physical characteristics of the subjects are summarized in Table 1. There were two experiments for each subject. In the first, a temperaturecontrolled room was maintained at $50 \pm 1{ }^{\circ} \mathrm{C}$ dry-bulb temperature with a relative humidity of $70 \pm 5 \%$. In the second, at least one week after the first experiment, the temperature was $25 \pm 1{ }^{\circ} \mathrm{C}$ dry-bulb temperature with a relative humidity of $40 \pm 5 \%$. In each experiment, the air movement was $50 \pm 10 \mathrm{~cm} /$ min. The subject wore protective clothing with an air respirator and entered the temperature-controlled room. After five minutes rest in a sitting position, the The recovery process was also measured for 10 minutes at room temperature subject performed bicycle ergometer exercises at $300 \mathrm{kpm} / \mathrm{min}$ for five minutes. The recovery process was also measured for 10 minutes at room temperature immediately after cessation of the ergometer exercise. The heart rate was recorded continuously with electrocardiographic monitors. Systolic and diastolic blood pressure were obtained on a sphygmomanometer by the auscultation method. Expired gas analysis for percent concentration of $\mathrm{O}_{2}$ and $\mathrm{CO}_{2}$ was performed continuously with a Fukuda Respilyzer. Pulmonary ventilation and respiratory frequency were calculated from the continuous readings of a Fukuda Respirometer. The data were analyzed by analysis of variance and Student's $t$-test.

The resting values for the heart rate and blood pressure are given in Table 1. As for the diastolic blood pressure, there was a tendency for it to increase with age. Fig. 1 shows the peak values of all parameters during exercise at $25^{\circ} \mathrm{C}$ and $50^{\circ} \mathrm{C}$. At the end of exercise, the heart rate achieved nearly a steady level at $25^{\circ} \mathrm{C}$, but not at $50^{\circ} \mathrm{C}$ due to the heat. There were no statistical 
Table 1. Physical characteristics, resting heart rate and resting blood pressure of each age group. Mean \pm S.D. are shown

\begin{tabular}{lrrrrrrr}
\hline & $\begin{array}{c}\text { Age } \\
\text { group } \\
\text { yr }\end{array}$ & $\begin{array}{c}\text { Height } \\
\text { cm }\end{array}$ & $\begin{array}{c}\text { Weight } \\
\text { kg }\end{array}$ & $\begin{array}{c}\text { BSA } \\
\mathrm{m}^{2}\end{array}$ & $\begin{array}{c}\text { Heart rate } \\
\text { beats/min }\end{array}$ & $\begin{array}{c}\text { Bystolic } \\
\text { mmHg }\end{array}$ & $\begin{array}{c}\text { Diastolic } \\
\text { mmHg }\end{array}$ \\
\hline Group 1 & 22.8 & 168.4 & 62.0 & 1.66 & 63.3 & 131.7 & 83.4 \\
(n=10) & \pm 2.4 & \pm 4.7 & \pm 3.5 & \pm 0.06 & \pm 5.5 & \pm 5.6 & \pm 9.4 \\
Group 2 & 32.3 & 167.8 & 68.6 & 1.73 & 66.1 & 131.9 & 87.4 \\
(n=11) & \pm 2.3 & \pm 3.8 & \pm 9.4 & \pm 0.11 & \pm 2.3 & \pm 8.7 & \pm 10.3 \\
Group 3 & 42.8 & 166.6 & 67.8 & 1.71 & 67.1 & 134.1 & 90.0 \\
(n=12) & \pm 2.8 & \pm 4.5 & \pm 10.0 & \pm 0.13 & \pm 4.5 & \pm 11.2 & \pm 5.8 \\
Group 4 & 52.7 & 162.9 & 61.9 & 1.62 & 69.6 & 135.5 & 91.2 \\
(n=7) & \pm 2.0 & \pm 6.1 & \pm 6.3 & \pm 0.09 & \pm 5.9 & \pm 3.3 & \pm 5.1 \\
\hline
\end{tabular}

differences in the peak heart rate between any of the age groups at either $25^{\circ} \mathrm{C}$ or $50^{\circ} \mathrm{C}$. The percent increase changes of heart rate during exercise and the percent decrease changes of heart rate during the recovery phase were calculated at both $25^{\circ} \mathrm{C}$ and $50^{\circ} \mathrm{C}$, but no significant differences were observed between any of the groups. The peak systolic blood pressure at $25^{\circ} \mathrm{C}$ in groups 2,3 and 4 were significantly higher than that of group 1 , but there were no significant differences between any of the groups at $50^{\circ} \mathrm{C}$. On the other hand, the peak diastolic blood pressure showed significant age-related differences at $50^{\circ} \mathrm{C}$, but not at $25^{\circ} \mathrm{C}$. The rate-pressure product revealed significant age-related differences at $25^{\circ} \mathrm{C}$, but not at $50^{\circ} \mathrm{C}$.

The oxygen consumption, pulmonary ventilation and respiratory frequency tended to increase at $50^{\circ} \mathrm{C}$ as compared to $25^{\circ} \mathrm{C}$. As with the pulmonary ventilation, group 4 revealed significantly greater values than groups 1 and 2 at $25^{\circ} \mathrm{C}$, but not at $50^{\circ} \mathrm{C}$. The older groups tended to have greater respiratory frequency, but the differences were not significant at either $25^{\circ} \mathrm{C}$ or $50^{\circ} \mathrm{C}$. There were no significant differences in oxygen consumption between any of the groups at either $25^{\circ} \mathrm{C}$ or $50^{\circ} \mathrm{C}$.

Age differences in cardiovascular responses were noted in systolic and diastolic blood pressure. The peak systolic blood pressure increased with age at $25^{\circ} \mathrm{C}$, which was consistent with the reports of previous workers, ${ }^{4,5)}$ On the contrary, the peak systolic blood pressure did not reveal age differences at $50^{\circ} \mathrm{C}$. This was because the younger groups showed greater increases in systolic blood pressure when exposed to heat. The rate-pressure product, which reflects the oxygen demand of the heart muscle, ${ }^{6}$ ) showed the same tendency as the systolic blood pressure. The diastolic blood pressure at rest and the peak diastolic blood pressure at $50^{\circ} \mathrm{C}$ increased significantly with advancing age. This was thought to be due to elevated peripheral resistance in the older men. ${ }^{7)}$ It is safe to say that the tendency for diastolic blood pressure to increase with age, observed at $25^{\circ} \mathrm{C}$, was augmented at $50^{\circ} \mathrm{C}$. The peak heart rate showed no age differences at either $25^{\circ} \mathrm{C}$ of $50^{\circ} \mathrm{C}$. Considering these results as a whole, it seems that age 

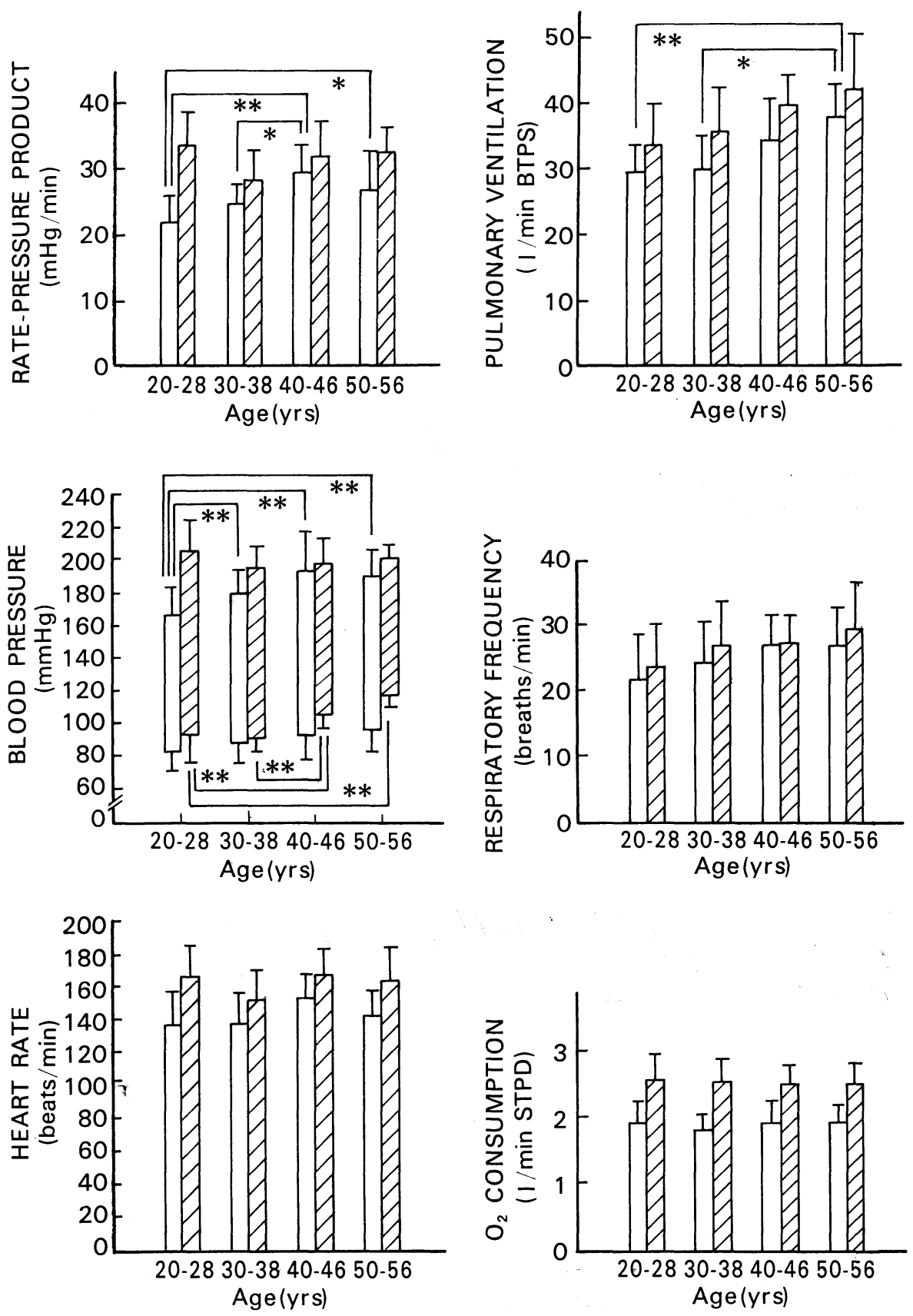

Significant difference between two groups.

$*: p<0.05$

$* *: p<0.01$

Fig. 1. Peak values of cadiorespiratory parameters at $25^{\circ} \mathrm{C}$ (unshaded columns)! and $50^{\circ} \mathrm{C}$ (shaded columns). Mean \pm S.D. are shown 
differences in peripheral vascular responses were clearer than those in cardiac responses with heat and exercise.

The oxygen consumption and respiratory frequency did not reveal age differences at either $25^{\circ} \mathrm{C}$ or $50^{\circ} \mathrm{C}$. It is known that the maximal oxygen consumption declines with advancing age. ${ }^{8)}$ This implies that the relative work load, expressed by percent ratio of oxygen consumption of the subject to his maximal oxygen consumption $\left(\% \mathrm{Vo}_{2} \max \right)$, was greater in the older groups in this experiment.

Age differences in cardiorespiratory responses to exercise were not observed except for the peak diastolic blood pressure at $50^{\circ} \mathrm{C}$. This means that the older firefighters could not work the same as the younger ones in real firefighting activities. Our results also exhibited that the heart rate and systolic blood pressure achieved nearly 170 beats/min and $200 \mathrm{~mm} \mathrm{Hg}$, respectively, at $50^{\circ} \mathrm{C}$ for five minutes. These intense cardiovascular responses, provoked by heat and exercise, may be stressful to older firefighters who have cardiovascular diseases. Especially important are ischemic heart diseases, which are considered to be an occupational hazard of firefighters because of their severe physical exercise ${ }^{9)}$ as well as inhalation of carbon monoxide. ${ }^{10,11)}$

As we reported previously, physiological responses upon exposure heat and exercise are augmented by antifire coats, probably due to the reduction of radiant heat transfer and effective evaporation. ${ }^{12)}$

In addition, in real firefighting activities, a firefighter must carry several pieces of equipment, such as an air respirator, a ladder, ropes and hoses. Thus, a nearmaximal to maximal work load could easily be attained during firefighting. ${ }^{2,9}$ )

Since the percentage of the older firefighters will increase in the future in Japan, better training programs to promote physical fitness with regard to age and early detection of ischemic heart diseases are necessary.

\section{ACKNOWLEDGEMENT}

The authors would like to express their appreciation to the members of the medical department of the Fire Science Laboratory of the Tokyo Fire Defence Board for their extensive technical assistance.

\section{REFERENCES}

1) Manning, J. E. and Griggs, T. R. (1983). Heart rates in firefighters using light and heavy breathing equipment: similar near-maximal exertion in response to multiple work load conditions, J. Occup. Med., 25, 215,

2) Puterbaugh, J. S. and Lawer, C. H. (1983). Cardiovascular effects of an exercise program: A controlled study among firemen, J. Occup. Med., 25, 581.

3) Kawaguchi, K. (1982). Kenkokanri no arikata (Comment on health care), Tokyo Shobo, 61, 24 (In Japanese). 
4) Hanson, J. S., Tabakin, B. S. and Levy, A.M. (1968). Comparative exercise-cardiorespiratory performance of normal men in the third, fourth, and fifth decades of life, Circulation, 37, 345.

5) DeVries, H. A. and Adams, G. W. (1972). Comparison of exercise responses in old and young men: I. The cardiac effort/total body effort relationship, J. Geront. 27, 344.

6) Duncan, H. W., Gardner, G. W. and Barnard, R. J. (1979). Physiological responses of men working in fire fighting equipment in the heat, Ergonomics, 22, 521.

7) Julius, J. S., Amery, A., Whitlock, L. S. and Conway, J. (1967). Influence of age on the hemodynamic responses to exercise, Circulation, 36, 222.

$8)$ Astrand, I. (1960). Aerobic work capacity in men and women with special reference to age, Acta. Physiol. Scand., 49, (Suppl. 169), 1.

9) Barnard, R. J., Gardner, G. W., Diaco, NB. V. and Kattus, A. A. (1975). Near-maximal ECG stress testing and coronary artery disease risk factor analysis in Los Angeles City firefighters, J. Occup. Med., 17, 693.

10) Takano, T. and Maeda, H. (1981). Exposure of firefighters to carbon monoxide, $J$. Combust. Toxicol., 8, 89.

11) Kurt, T. L. and Peters, J. M. (1975). Epidemiology of cardiac risks in firefighters with Holter electrocardiograms and carbon monoxide sampling, Circulation, 52, (Suppl. 11), 204.

12) Motohashi, Y., Miyazaki, Y., Takano, T., Nojiri, T. and Sekine, H. (1983). Effects to firefighters of exercise in a hot environment when wearing the anti-fire coat, Jpn.J. Hyg., $38,589$.

Department of Hygiene and Environmental Health,

Faculty of Medicine,

Tokyo Medical and Dental University

and Takehito TAKANO

1-545, Yushima, Bunkyo-ku, Tokyo 113, Japan

(Received July 4, 1985 and in revised form September 3, 1985) 